\title{
TOXICITY RESEARCH OF SMOULDERING AND FLAMING PINE TIMBER TREATED WITH FIRE RETARDANT SOLUTIONS
}

\author{
Zbignev Karpovič ${ }^{1}$, Ritoldas Šukys ${ }^{2}$, Rimvydas Gudelis ${ }^{3}$ \\ ${ }^{1,2}$ Department of Labour Safety and Fire Protection, Vilnius Gediminas Technical University, \\ Sauletekio al. 11, LT-10223 Vilnius, Lithuania \\ ${ }^{3}$ Fire and Rescue Department under The Ministry of Interior, \\ Švitrigailos g. 18, LT-03223 Vilnius, Lithuania \\ E-mails: 1'zbigis@gmail.com (corresponding author); ${ }^{2}$ ritoldas.sukys@vgtu.lt; ${ }^{3}$ rgudelis@gmail.com \\ Received 29 Jan. 2011; accepted 15 Jun. 2012
}

\begin{abstract}
The emission of toxic gaseous combustion products from timber constructions influences on the time required for evacuation of people from a building during a fire. In order to prolong the time interval until inflammation of timber constructions, fire retardant solutions are used. It is relevant and very important to determine how the emission of toxic gaseous combustion products from pine timber non-treated and treated with fire retardant solutions used in Lithuania differs during thermal destruction. Measuring carbon monoxide (CO) emissions, the paper focuses on toxicity analysis determined by nonstandard and standard research methods of smouldering and flaming pine timber, both non-treated and treated with fire retardant solutions. The description comprises specimens used in research and their preparation, nonstandard and standard research equipment and methods determining toxicity of smouldering and flaming pine timber, both non-treated and treated with fire retardant solutions. The article presents the analysis of experimental results processed by statistical methods.
\end{abstract}

Keywords: pine timber, smouldering, flaming, toxicity, carbon monoxide.

\section{Introduction}

Timber is one of the main building materials, long-time used in construction as well as most widely applied. There are many building materials produced from raw materials however many villagers live in wooden buildings. Many household buildings are wooden (Nagrodzka, Maloziec 2011; Teischinger 2010).

Use of timber in construction is limited due to easy flammability and quick spreading of fire. Even at the temperature of $300{ }^{\circ} \mathrm{C}$ timber under thermal destruction emits a sufficient amount of flammable gas causing inflammation and combustion (Drysdale 1998).

Timber combustion is a complicated process. Thermal destruction of timber has been analysed and presented thoroughly by a number of authors (Jeguirim, Trouvé 2009; Windeisen, Wegener 2008; Hosoya et al. 2007; Frey et al. 2009). Two types of timber combustion may be distinguished: smouldering and flaming. The first one is considered to be more dangerous as it remains invisible for a period of time. Besides, smouldering results in greater emissions of toxic gaseous combustibility products. The intensity of combustibility, the quality and quantity of the emitted toxic gaseous combustibility products depend on the type of timber, its moisture, and circumstances of combustion (Stec, Hull 2010).

Combustion produces smoke - the mix of gas, fumes and soot. Researches prove that toxic gaseous combustibility products that are found in smoke impede breathing, reduce range of visibility and prolong time needed for evacuation of people (Papinigis et al. 2010; Tserng et al. 2011). It poses $60-80 \%$ of all deaths in fires. During the last five years, on an average 262 people died in fires in Lithuania annually (Brushlinsky et al. 2012). In 2011, 8 people per 100 thousand people died in fires in Lithuania. This indicator is one of the highest among the European Union countries. In 2008 and 2011, in terms of this indicator Lithuania overtook Latvia and Estonia (Fire and Rescue Analysis 2012).

According to the fire safety requirements, the combustibility of timber constructions in a building must be reduced. Usually, the combustibility of timber constructions is reduced by treating them with fire retardant solutions (Wang et al. 2008). During combustion, the temperature of timber treated with fire retardant solutions is lower, the layer of carbon is thicker, the rapidity of heat emission and weight reduction is decreased (Jiang et al. 2010; Hagen et al. 2009).

Timber (Šaučiuvènas et al. 2011; Kängsepp et al. 2011; Mačiulaitis, Praniauskas 2010; Bednarek et al. 2009; Juodeikienè 2009; Bednarek, Kaliszuk-Wietecka 2007), fire retardants (Glenn et al. 2012; Babrauskas et al. 2011; Gałaj et al. 2011a; Grigonis et al. 2011; Karpovič et al. 2010; Karpovič 2009; Vobolis, Albrektas 2009; Pereyra, Giudice 2009; Półka 2008), timber treated with fire retardant solutions in connection with its toxicity during combustion (Gałaj et al. 2011b; Šukys, Kar- 
povič 2010; Karpovič, Šukys 2009; Paul et al. 2008; Lestari et al. 2006) and computer modelling for combustion (Capote et al. 2012; Keshavarz et al. 2012; Fouladgar et al. 2012; Vaidogas et al. 2012; Cheng, Hadjisophocleous 2011; Gałaj 2009) have been already analysed in the field of fire safety. However the toxicity of smouldering and flaming pine timber which is non-treated and treated with fire retardant solutions has not yet been studied within an integrated approach. This issue is very important in Lithuania and globally. Toxicity of construction products and (or) interior decoration products during fire is regulated in few countries (Gann et al. 2011). The toxicity of construction products in Lithuania is not regulated either. Such research and analysis could open up opportunities for making required decisions in order to reduce number of victims in fires.

The aim of the work: using nonstandard and standard research equipment and methods, to determine the toxicity by assessing $\mathrm{CO}$ of smouldering and flaming pine timber, both non-treated and treated with fire retardant solutions.

\section{Specimens, research equipment and research methods}

Pine timber specimens non-treated and treated with fire retardant solutions used in tests were cut from defect-free (i.e. crack-free) pine timber boards of $0.2 \mathrm{~m}$ in width, $0.02 \mathrm{~m}$ in thickness and $530 \mathrm{~kg} / \mathrm{m}^{3}$ of average density. Pine timber boards were naturally dried to humidity of less than $15 \%$. It was treated with fire retardant solutions Flamasepas-2 and BAK-1 (with $\mathrm{K}_{2} \mathrm{CO}_{3}$ as the main component) according to the recommendations of the producers, i.e. brushing the surface with not less than $500 \mathrm{ml} / \mathrm{m}^{2}$ of the fire retardant solution. To ensure fire retardant solutions do not evaporate and penetrate the treated timber as deeply as possible, surfaces of the pine timber boards were covered with foil for 24 hours. The pine timber boards treated with fire retardant solutions were naturally dried to humidity of less than $15 \%$.

The fire retardant solutions Flamasepas-2 and BAK1 (hereinafter - A and B) used for the treatment of timber have been certified and used in Lithuania.

This research was performed for three groups of specimens:

- pine timber specimens non-treated with fire retardant solutions;

- pine timber specimens treated with the fire retardant solution A;

- pine timber specimen treated with the fire retardant solution B.

The nonstandard research on toxicity of smouldering pine timber - both non-treated and treated with fire retardant solutions - was performed in the Main School of Fire Service in Warsaw. The research equipment for toxic combustions products emitted from solid materials after the impact of a heat flux was used (Fig. 1).

The aforementioned equipment can be used to determine toxic combustibility products and their quantity emitted while affecting a specimen with different heat fluxes. The possible range of a heat flux was from 2 to
$80 \mathrm{~kW} / \mathrm{m}^{2}$. The necessary condition for the research was set: thermal destruction had to proceed without breaking into flames, i.e. the tested specimens had to be smouldering. Two heat fluxes - one of $8 \mathrm{~kW} / \mathrm{m}^{2}$ and another of $10 \mathrm{~kW} / \mathrm{m}^{2}$ - were used in this research. By affecting the specimen with heat fluxes of $8 \mathrm{~kW} / \mathrm{m}^{2}$ and $10 \mathrm{~kW} / \mathrm{m}^{2}$, the conditions were established for the emission of the main amount of toxic combustion products. At the heat fluxes of less than $8 \mathrm{~kW} / \mathrm{m}^{2}$, the temperature on the specimens did not reach $160{ }^{\circ} \mathrm{C}$; while at the heat fluxes higher than $10 \mathrm{~kW} / \mathrm{m}^{2}$, the specimens inflamed.

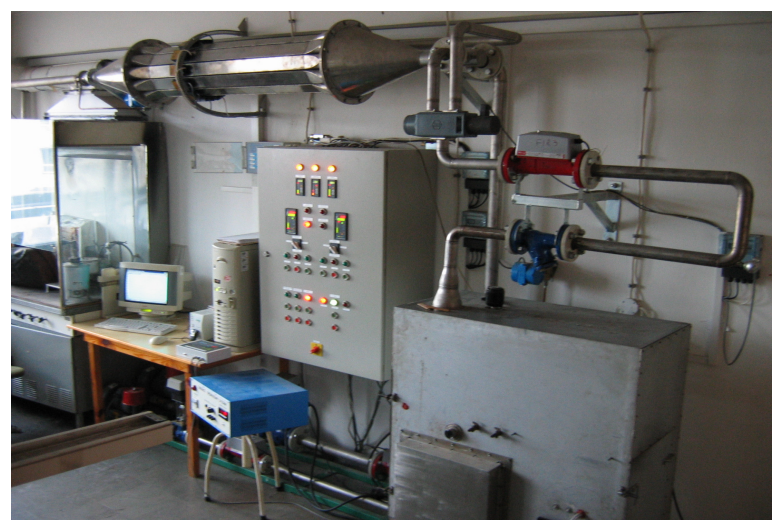

Fig. 1. Research equipment for toxic combustion products emitted from solid materials affected by a heat flux

5 specimens in every group were tested. The timescale for one test course was up to $55 \mathrm{~min}$. The dimensions of the specimens were $0.2 \times 0.2 \times 0.02 \mathrm{~m}$.

The standard research on toxicity of smouldering pine timber - both non-treated and treated with fire retardant solutions - was performed in the Main School of Fire Service in Warsaw using the cone calorimeter that corresponds to the requirements of the ISO 5660-1:2002 standard. The cone calorimeter is depicted in Fig. 2.

Before each of the tests, a specimen of $0.1 \times 0.1 \times$ $0.02 \mathrm{~m}$ dimensions was weighted and folded in foil except for the surface exposed to a heat flux. The prepared specimen was placed in the special frame, which was laid onto the scale under the heating cone.

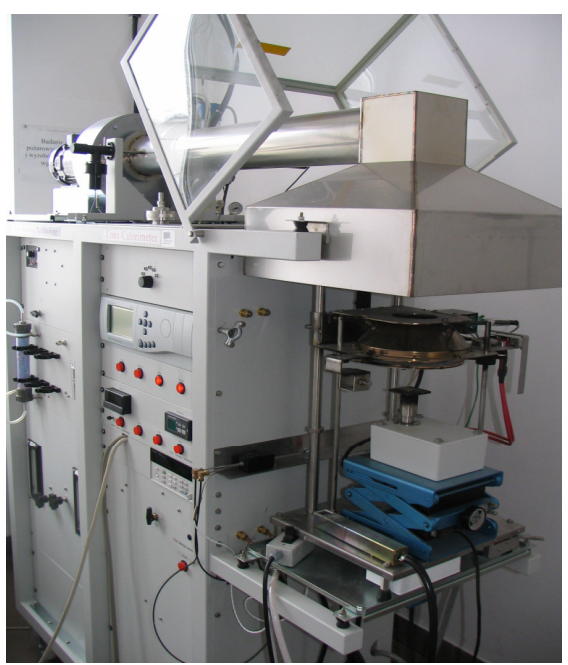

Fig. 2. A view of the cone calorimeter 
5 specimens in every group were tested. During the tests, the specimens were affected by the heat flux of $30 \mathrm{~kW} / \mathrm{m}^{2}$. No piloted ignition was used. Affecting the specimens with the given heat flux and with no piloted ignition, the conditions for smouldering were established and the temperature on the surface of the specimens did not exceed $270{ }^{\circ} \mathrm{C}$. The duration of each toxicity test of the smouldering pine timber non-treated and treated with fire retardant solutions amounted to $15 \mathrm{~min}$.

The nonstandard research on toxicity of flaming pine timber - both non-treated and treated with fire retardant solutions - was performed in the Main School of Fire Service in Warsaw. The confined cabin containing the research equipment was used. The interior of the confined cabin is depicted in Fig. 3.

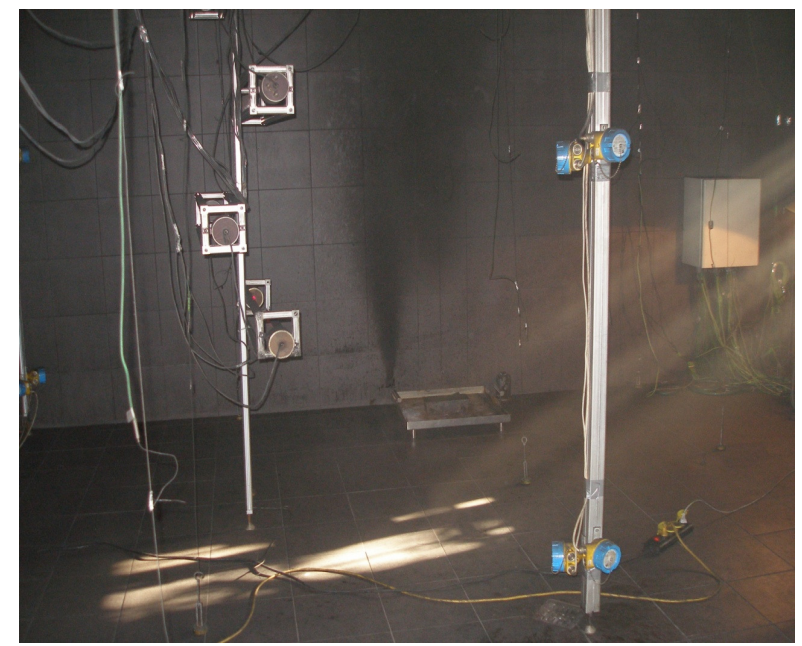

Fig. 3. Interior of the research equipment

The two walls of the cabin of $5 \times 5 \times 2.8 \mathrm{~m}$ were made of aluminium and glass. The other two brick walls were covered with ceramic tiles. The measuring equipment for CO concentration was located in the cabin. During the research, the concentration of $\mathrm{CO}$ was measured by nine electrochemical sensors of "ALTER SA MG 72" type, accurate to $1 \mathrm{ppm}$. The sensors were mounted on three columns at three heights in the research cabin: $0.35 \mathrm{~m}$, $1.4 \mathrm{~m}$ and $2.5 \mathrm{~m}$. The scheme of the vertical and horizontal positioning of the sensors measuring $\mathrm{CO}$ concentration in the research cabin is depicted in Fig. 4.

During each test, a steel tray with three specimens was placed inside the unventilated research cabin and combusted so that the flame could affect the surface of the specimens treated with fire retardant solutions. The specimens were combusted by pouring and firing up $0.4 l$ of denatured alcohol in the steel tray. During every test, the steel tray with specimens was placed in the same place of the test cabin near the back wall.

9 specimens in every group were tested. The dimensions of the specimens were $0.2 \times 0.2 \times 0.02 \mathrm{~m}$. After inflammation of a specimen, the doors of the cabin were closed. During the tests, the changes in CO concentration level were measured and saved in different points of the test cabin every $5 \mathrm{~s}$. When fire parameters stopped altering, the ventilation system was started and the test was closed.

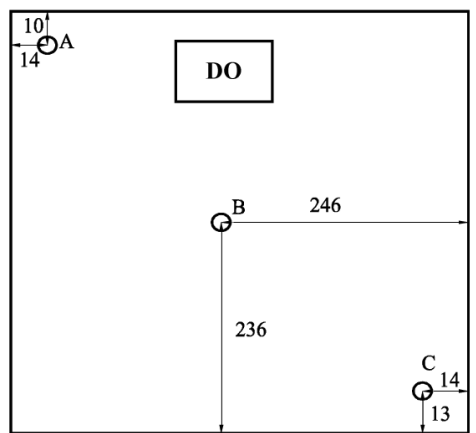

a)

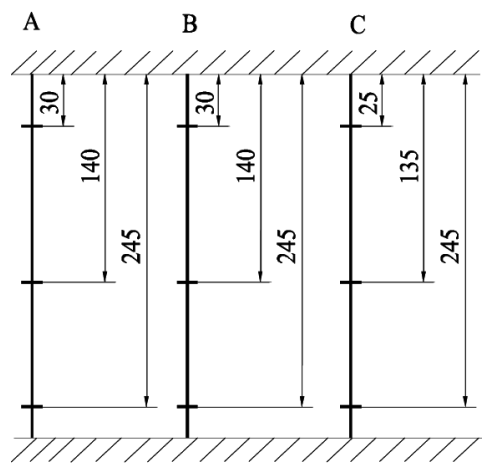

b)

Fig. 4. Scheme of vertical (a) and horizontal (b) positioning for the sensors measuring $\mathrm{CO}$ concentration, installed on $\mathrm{A}, \mathrm{B}$ and $\mathrm{C}$ columns (numbers - in cm; DO - burning object)

The standard research on toxicity of flaming pine timber non-treated and treated with fire retardant solutions was performed in the Main School of Fire Service in Warsaw. The cone calorimeter that corresponds to the requirements of ISO 5660-1:2002 standard was used. The description of the cone calorimeter and research methods for the determination of toxicity of flaming pine timber - both non-treated and treated with fire retardant solutions which was described above was the same as the standard research methods used for testing smouldering pine timber, both treated and non-treated with fire retardant solutions.

During the tests of flaming timber, the specimens were affected by the heat flux of $30 \mathrm{~kW} / \mathrm{m}^{2}$ together with piloted ignition of $10 \mathrm{kV}$. Affecting the specimens with the given heat flux together with piloted ignition, the conditions for flaming were established.

The piloted ignition source was formed from two parallel electrodes located at the height of $1 \mathrm{~cm}$ above the surface of a specimen. The electrodes were attached to the mechanism of piloted ignition, which regulates the electrodes to approach the surface of the specimens and to distance from it. When approaching the surface of the specimens, the electric current was transmitted through the electrodes at a fixed periodicity. It created a spark at the ends of the electrodes.

Subjected to time, the obtained results of toxicity of smouldering and flaming pine timber - both non-treated and treated with fire retardant solutions - determined by nonstandard and standard research equipment were analysed statistically. The arithmetic averages were developed to the statistical selections of the results $x_{1}, x_{2}, \ldots . x_{n}$ (Sakalauskas 2003). 
The arithmetic averages of the statistical selections of the results were processed using the programme "Statistika 8". The negative exponential function highreflecting test results was applied. The correlation coefficients $r$ and linear and non-linear curve regression equations formed by the programmes "Statistika 8" and "TableCurve 2D" are also presented (Sakalauskas 2003; Kleiza 2003).

\section{Experimental results and discussion}

The results of the nonstandard research on toxicity of smouldering timber

The average emission of $\mathrm{CO}$ depending of the heat flux and the specimens is shown in Figs 5-6.

Affecting pine timber specimens with the heat flux of $8 \mathrm{~kW} / \mathrm{m}^{2}$ in $300 \mathrm{~s}$ on the average, after the surface temperature of the specimen reached the average of $140^{\circ} \mathrm{C}$, the sensor started registering CO (Fig. 5). The temperature was reached at which pine timber specimens emitted $\mathrm{CO}$ during thermal destruction.

Affecting pine timber specimens treated with the fire retardant solution A with the heat flux of $8 \mathrm{~kW} / \mathrm{m}^{2}$ in $420 \mathrm{~s}$ on the average, after the surface of the specimen reached the mean temperature of $165^{\circ} \mathrm{C}$, the sensor started registering $\mathrm{CO}$ (Fig. 4). Affecting pine timber specimens treated with the fire retardant solution $B$ by the heat flux of $8 \mathrm{~kW} / \mathrm{m}^{2}$ in $365 \mathrm{~s}$ on the average, after the surface of the specimen reached the mean temperature of $156^{\circ} \mathrm{C}$, the sensor started registering CO (Fig. 5). Due to the protective features of fire retardants to impede gas emission during thermal destruction, the emission of $\mathrm{CO}$ from pine timber specimens treated with the fire retardant solutions $\mathrm{A}$ and $\mathrm{B}$ started after a longer period of time and at a higher surface temperature as compared to the emission of $\mathrm{CO}$ from the non-treated pine timber specimens.
Affecting the non-treated pine timber specimens with the heat flux of $10 \mathrm{~kW} / \mathrm{m}^{2}$ in $170 \mathrm{~s}$ on the average, after the surface of the specimens reached the mean temperature of $135^{\circ} \mathrm{C}$, the sensor started registering $\mathrm{CO}$ (Fig. 6).

Affecting pine timber specimens treated with the fire retardant solution A with the heat flux of $10 \mathrm{~kW} / \mathrm{m}^{2}$ in $270 \mathrm{~s}$ on the average, after the surface of the specimen reached the mean temperature of $170{ }^{\circ} \mathrm{C}$, the sensor started registering $\mathrm{CO}$ (Fig. 6).

Affecting pine timber specimens treated with the fire retardant solution B by the heat flux of $10 \mathrm{~kW} / \mathrm{m}^{2}$ in $300 \mathrm{~s}$ on the average, after the surface of the specimen reached the mean temperature of $178^{\circ} \mathrm{C}$, the sensor started registering $\mathrm{CO}$ (Fig. 6).

Increasing the heat flux and the speed of temperature rise, the emission of $\mathrm{CO}$ during thermal destruction from pine timber specimens non-treated and treated with fire retardant solutions started after a shorter period of time.

At the beginning of the tests, pine timber specimens treated with the fire retardant solutions A and B emitted $\mathrm{CO}$ more intensely as compared to the non-treated pine timber specimens in the period up to $2700 \mathrm{~s}\left(8 \mathrm{~kW} / \mathrm{m}^{2}\right)$ and up to $1900 \mathrm{~s}\left(10 \mathrm{~kW} / \mathrm{m}^{2}\right)$. However, this emission altered insignificantly after $1500 \mathrm{~s}$ at $8 \mathrm{~kW} / \mathrm{m}^{2}$, when the surface of the specimens reached the mean temperature of $211^{\circ} \mathrm{C}$ and after $1000 \mathrm{~s}$ at $10 \mathrm{~kW} / \mathrm{m}^{2}$ when the surface of the specimens reached the mean temperature of $260^{\circ} \mathrm{C}$. The emission of $\mathrm{CO}$ from non-treated pine timber was growing during the entire research (Figs 5-6).

In the course of the tests during the initial $2700 \mathrm{~s}$, the non-treated pine timber specimens affected by the heat flux of $8 \mathrm{~kW} / \mathrm{m}^{2}$ emitted 2.8 times less $\mathrm{CO}$; and during the initial $1900 \mathrm{~s}$, the non-treated pine timber specimens affected by the heat flux of $10 \mathrm{~kW} / \mathrm{m}^{2}$ emitted 3.1 times less $\mathrm{CO}$ as compared to the pine timber specimens treated with the fire retardant solutions A and B (Figs 5-6).

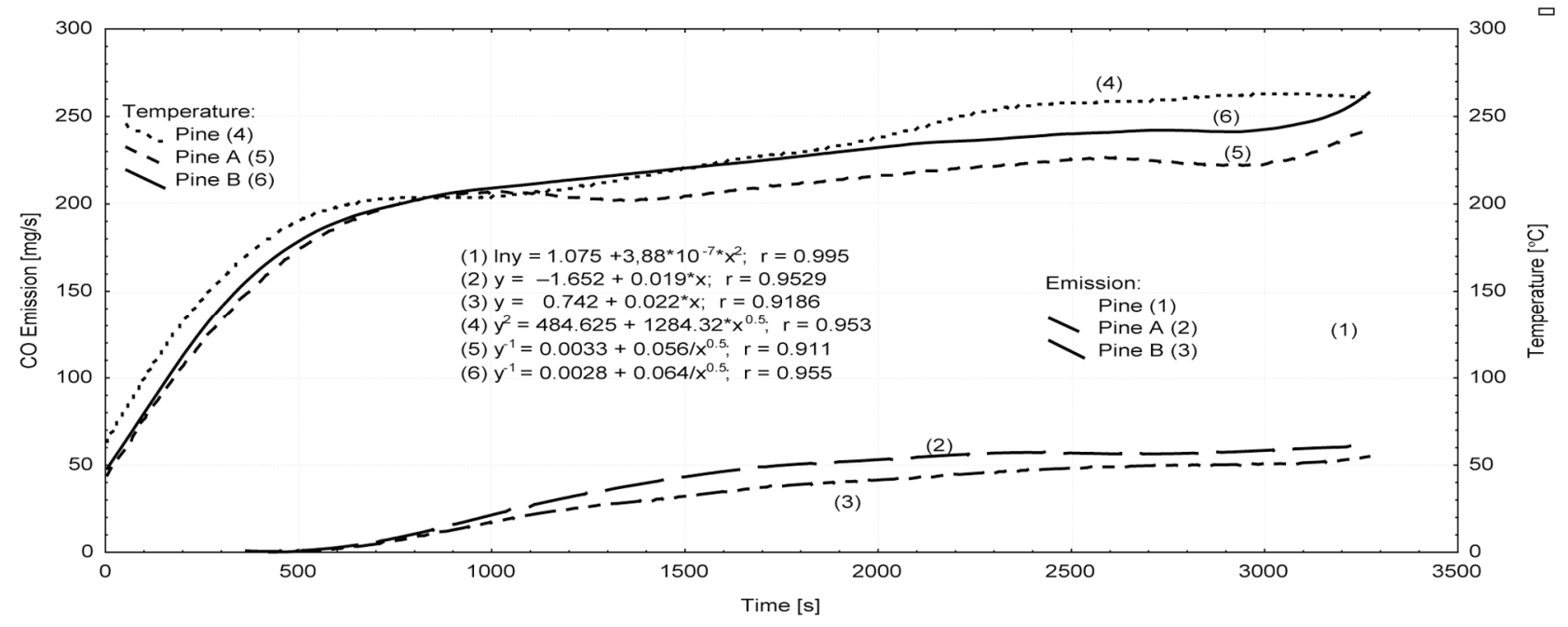

Fig. 5. Average emissions of CO from tested specimens and alternation of average temperature on the surface of tested specimens affected by heat sources of $8 \mathrm{~kW} / \mathrm{m}^{2}$ subjected to time: (1) - non-treated pine timber specimens; (2) - pine timber specimens treated with $A ;(3)$ - pine timber specimens treated with B; (4) - non-treated pine timber specimens; (5) - pine timber specimens treated with A; (6) - pine timber specimens treated with B 


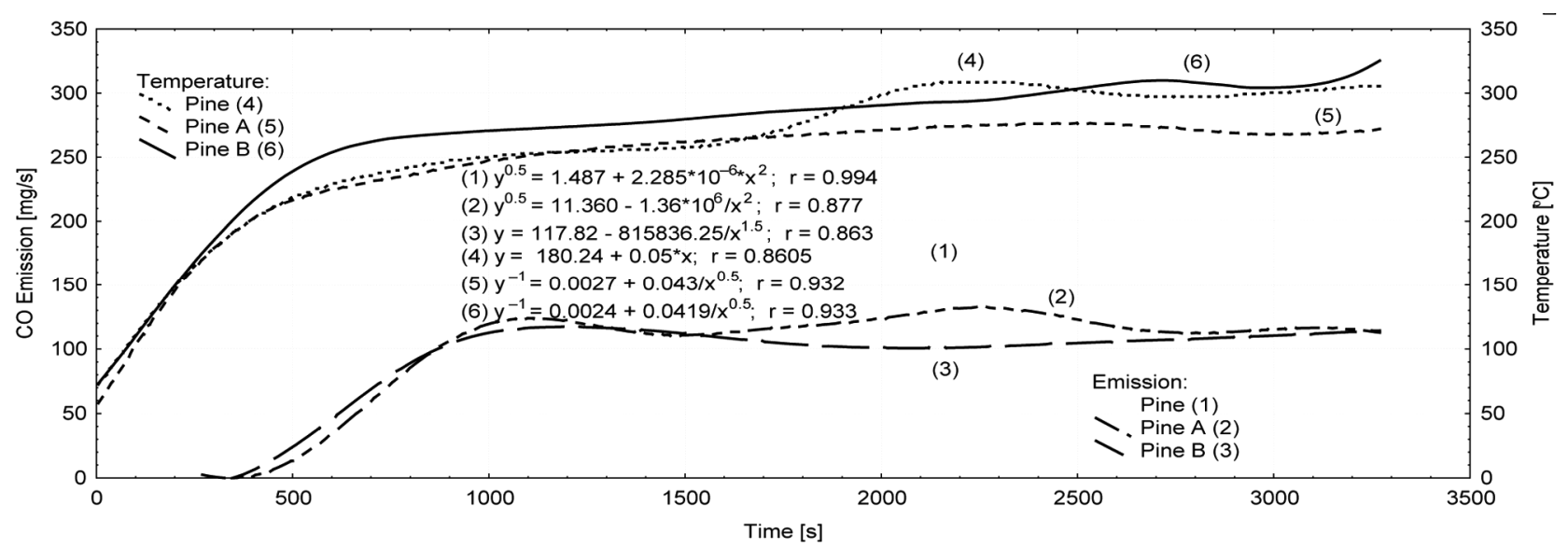

Fig. 6. Average emissions of $\mathrm{CO}$ from tested specimens and alternation of average temperature on the surface of tested specimens affected by heat sources of $10 \mathrm{~kW} / \mathrm{m}^{2}$ subjected to time: (1) - non-treated pine timber specimens; (2) - pine timber specimens treated with A; (6) - pine timber specimens treated with B

The fire retardants reduced the temperature on the surface of the specimens and the delivery of oxygen to the pyrolisis zone. It increased the emission of $\mathrm{CO}-$ thermal destruction product of partial oxidation - at the beginning of the tests. In the course of the tests, the emission of $\mathrm{CO}$ from the pine timber specimens treated with the fire retardant solutions $\mathrm{A}$ and $\mathrm{B}$ as compared to the non-treated pine timber specimens altered insignificantly. The protective features of fire retardants impeded the penetration of temperature to the deeper layers of timber and stopped the emission of thermal destruction gas.

Comparing pine timber specimens treated with the fire retardant solution A with specimens treated with the fire retardant solution $\mathrm{B}$, pine timber specimens treated with the fire retardant solution $\mathrm{A}$ affected with the heat flux of $8 \mathrm{~kW} / \mathrm{m}^{2}$ emitted on average 1.2 times more $\mathrm{CO}$ than pine timber specimens treated with the fire retardant solution B. Pine timber specimens treated with the fire retardant solution A affected by the heat flux of $10 \mathrm{~kW} / \mathrm{m}^{2}$ emitted on average 1.1 times more $\mathrm{CO}$ than pine timber specimens treated with the fire retardant solution B (Figs 5-6). The difference in the emission of CO depended on the unequal microscopic structure, inequality in wood tar content and in the composition of fire retardants.

\section{The results of the standard research on toxicity} of smouldering timber

The average alternation of $\mathrm{CO}$ concentration depending on the specimens is depicted in Fig. 7.

At the beginning of the research concentration of $\mathrm{CO}$ for pine timber specimens treated with the fire retardant solutions $\mathrm{A}$ and $\mathrm{B}$ in the period up to $300 \mathrm{~s}$ was growing intensely. After $300 \mathrm{~s}$ the concentration of the $\mathrm{CO}$ for pine timber specimens treated with the fire retardants A and B was changing insignificantly and did not exceed the value of $0.13 \mathrm{~kg} / \mathrm{kg}$ ( $\mathrm{kg} / \mathrm{kg}$ - the fraction of CO mass to the mass of air). In the period up to $350 \mathrm{~s}$, pine timber specimens treated with the fire retardant solutions A and B as compared to the non-treated pine timber specimens obtained the highest concentration of $\mathrm{CO}$ due to the same reason as mentioned above. The concentration of $\mathrm{CO}$ for non-treated pine timber specimens was growing during the entire research and reached the value of $0.16 \mathrm{~kg} / \mathrm{kg}$ (Fig. 7).
The highest concentration of $\mathrm{CO}$ for pine timber specimens treated with the fire retardant solutions $\mathrm{A}$ and B was about $20 \%$ lower than the highest concentration of $\mathrm{CO}$ for the non-treated pine timber specimens. During the initial $350 \mathrm{~s}$ the concentration of $\mathrm{CO}$ for pine timber specimens treated with the fire retardant solutions $\mathrm{A}$ and $\mathrm{B}$ was about $20 \%$ higher than the concentration of $\mathrm{CO}$ for the non-treated pine timber specimens (Fig. 7).

Comparing pine timber specimens treated with the fire retardant solution A with specimens treated with the fire retardant solution $\mathrm{B}$, the concentration of $\mathrm{CO}$ for pine timber specimens treated with the fire retardant solution A was on average 1.1 times lower than the concentration of $\mathrm{CO}$ for pine timber specimens treated with the fire retardant solution B (Fig. 7).

The results of the toxicity of the nonstandard research on toxicity of flaming timber

The average concentration of $\mathrm{CO}$ near the burning object, measured by the sensor mounted on the B column in the centre of the cabin at the height of 1.4, depending on the specimens is depicted in Fig. 8.

At the beginning of the research, in the period up to $260 \mathrm{~s}$, the concentration of $\mathrm{CO}$ for all groups of pine timber specimens grew intensely. After $260 \mathrm{~s}$, the concentration of the $\mathrm{CO}$ for pine timber specimens treated with the fire retardant solutions $\mathrm{A}$ and $\mathrm{B}$ altered insignificantly and did not exceed the value of $6 \times 10^{-5} \mathrm{~kg} / \mathrm{kg}$. The concentration of $\mathrm{CO}$ for the non-treated pine timber specimens grew during the entire research and reached the value of $7.2 \times 10^{-5} \mathrm{~kg} / \mathrm{kg}$ (Fig. 8).

During flaming of the non-treated pine timber specimens, the sensor started registering $\mathrm{CO}$ during initial seconds of the tests. In the case of the flame combustion of pine timber specimens treated with the fire retardant solutions $\mathrm{A}$ and $\mathrm{B}$, the sensor started registering $\mathrm{CO}$ after $62 \mathrm{~s}$ on the average (Fig. 8). Due to the protective features of fire retardants, the emission of $\mathrm{CO}$ from pine timber specimens treated with the fire retardant solutions $\mathrm{A}$ and $\mathrm{B}$ started after a longer period of time comparing with the emission of $\mathrm{CO}$ from the non-treated pine timber specimens. 


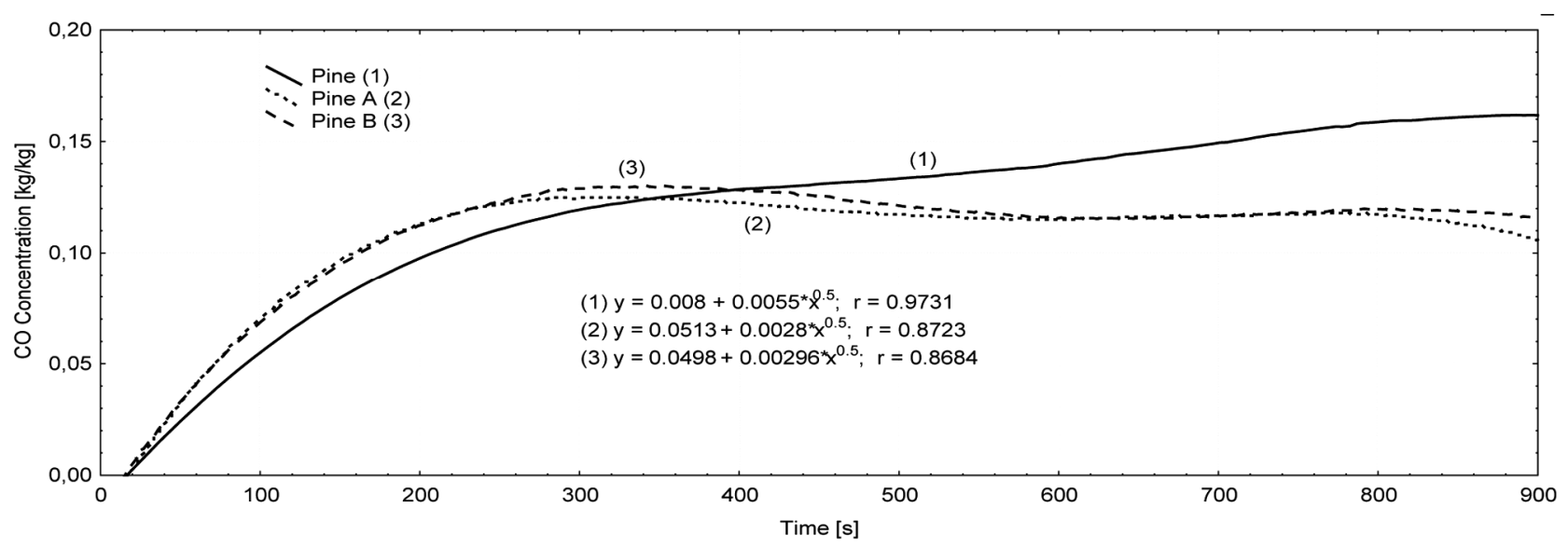

Fig. 7. Alternation of average CO concentration obtained during smouldering of tested specimens subjected to time: (1) - non-treated pine timber specimens; (2) - pine timber specimens treated with A; (3) - pine timber specimens treated with B

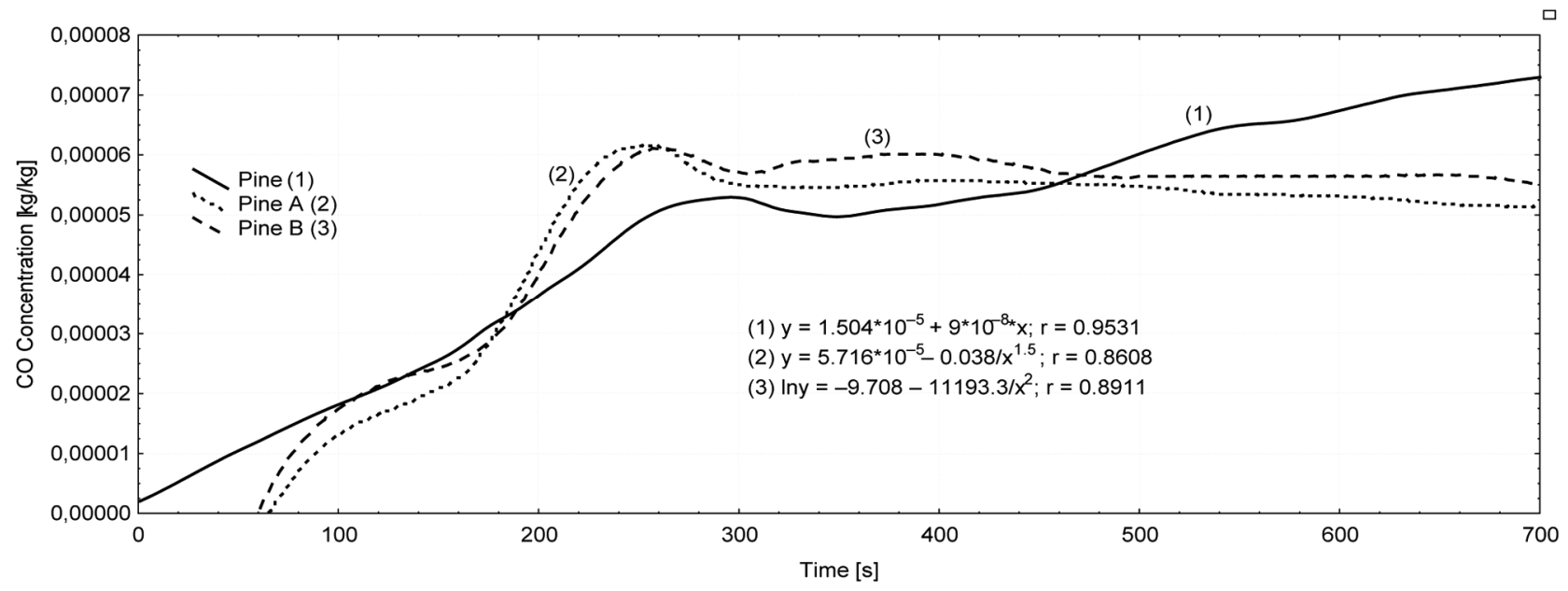

Fig. 8. Alternation of average CO concentration measured by the sensor in the centre of the compartment at the height of $1.4 \mathrm{~m}$ obtained during flame combustion of tested specimens subjected to time: (1) - non-treated pine timber specimens; (2) - pine timber specimens treated with $A ;(3)$ - pine timber specimens treated with $B$

The highest concentration of $\mathrm{CO}$ for pine timber specimens treated with the fire retardant solutions $\mathrm{A}$ and $\mathrm{B}$ was on average 1.2 times lower than the highest concentration of $\mathrm{CO}$ for the non-treated pine timber specimens. During the initial $180 \mathrm{~s}$ the concentration of CO for pine timber specimens treated with the fire retardant solutions $\mathrm{A}$ and $\mathrm{B}$ was averagely 1.4 times lower than the concentration of $\mathrm{CO}$ for the non-treated pine timber specimens. At the time interval of $180-460 \mathrm{~s}$ the obtained concentration of $\mathrm{CO}$ for pine timber specimens treated with the fire retardant solutions $\mathrm{A}$ and $\mathrm{B}$ was 1.2 times higher than the concentration of $\mathrm{CO}$ for the non-treated pine timber specimens (Fig. 8).

Comparing pine timber specimens treated with the fire retardant solution A with specimens treated with the fire retardant solution $\mathrm{B}$, the concentration of $\mathrm{CO}$ of pine timber specimens treated with the fire retardant solution A was on average 1.2 times lower than the concentration of $\mathrm{CO}$ for pine timber specimens treated with the fire retardant solution B (Fig. 8).

The results of the standard research on toxicity of flaming timber
The average alternation of $\mathrm{CO}$ concentration depending on the specimens is depicted in Fig. 9.

At the beginning of the tests in the period up to $200 \mathrm{~s}$, the concentration of $\mathrm{CO}$ for pine timber specimens treated with the fire retardant solutions $\mathrm{A}$ and $\mathrm{B}$ grew intensely and reached $0.019 \mathrm{~kg} / \mathrm{kg}$ and $0.022 \mathrm{~kg} / \mathrm{kg}$ respectively. After $200 \mathrm{~s}$, the average concentration of CO for pine timber specimens treated with the fire retardant solutions A and B began reducing. The concentration of $\mathrm{CO}$ for the non-treated pine timber specimens was growing up to $400 \mathrm{~s}$ on the average and did not exceed the value of $0.005 \mathrm{~kg} / \mathrm{kg}$ (Fig. 9).

The highest concentration of $\mathrm{CO}$ for pine timber specimens treated with the fire retardant solutions A and $\mathrm{B}$ was on average 4.4 times higher than the highest concentration of $\mathrm{CO}$ for the non-treated pine timber specimens. During the research, the concentration of $\mathrm{CO}$ for pine timber specimens treated with the fire retardant solutions $\mathrm{A}$ and $\mathrm{B}$ was on average 1.8 times higher than the concentration of $\mathrm{CO}$ for the non-treated pine timber specimens (Fig. 9). The fire retardants reduced the delivery of oxygen to the pyrolisis zone by increasing the emission of thermal destruction product of partial oxidation $-\mathrm{CO}$. 


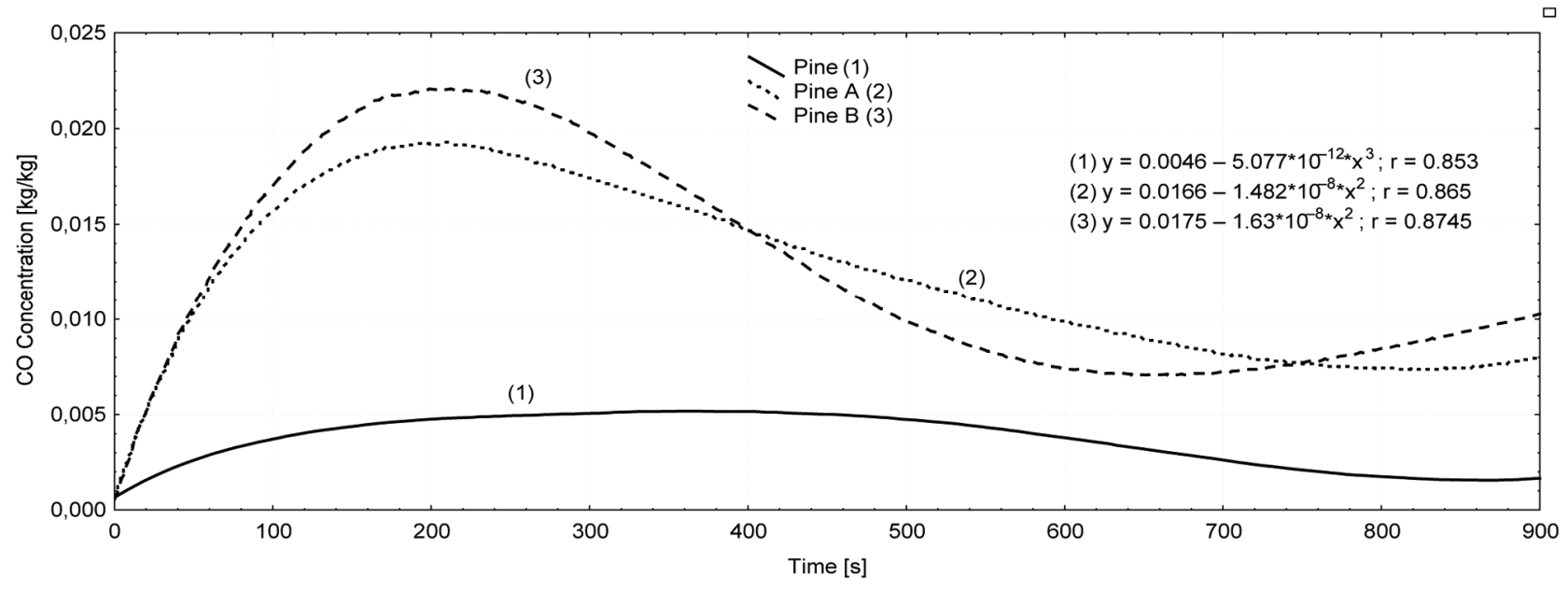

Fig. 9. Alternation of average $\mathrm{CO}$ concentration obtained during flame combustion of tested specimens subjected to time: (1) - nontreated pine timber specimens; (2) - pine timber specimens treated with A; (3) - pine timber specimens treated with B

Comparing pine timber specimens treated with the fire retardant solution $A$ with specimens treated with the fire retardant solution $\mathrm{B}$, the concentration of $\mathrm{CO}$ for pine timber specimens treated with the fire retardant solution A was on average 1.1 times lower than the concentration of $\mathrm{CO}$ for pine timber specimens treated with the fire retardant solution B (Fig. 9). The difference in the emission of $\mathrm{CO}$ depended on the unequal microscopic structure, inequality in wood tar content and in the composition of fire retardants.

\section{Conclusions}

1. The beginning of the emission of $\mathrm{CO}$ from smouldering pine timber non-treated and treated with fire retardant solutions depends on the temperature and time at which it starts emitting. On average, the emission of $\mathrm{CO}$ from pine timber treated with fire retardant solutions starts after a 1.5 times longer time period after the beginning of the test and at the temperature is on average 1.2 times higher as compared to the non-treated pine timber. This is explained by the protective features of fire retardants to stop the emission of thermal destruction gas from pine timber treated with fire retardant solutions.

2. During smouldering of pine timber non-treated and treated with fire retardant solutions:

- fire retardants reduce the temperature on the surface of timber and the delivery of oxygen to the pyrolisis zone by increasing the emission of $\mathrm{CO}$;

- the emission of CO from treated smouldering pine timber is higher during the initial seconds of the test than the emission of $\mathrm{CO}$ from the nontreated smouldering pine timber;

- during the test the emission of $\mathrm{CO}$ from pine timber treated with fire retardant solutions alters insignificantly while the emission of $\mathrm{CO}$ from the non-treated pine timber intensifies;

- on average, pine timber treated with the fire retardant solution A emitted 1.2 times more $\mathrm{CO}$ than pine timber treated with the fire retardant solution B (nonstandard research equipment);
- on average, pine timber treated with the fire retardant solution A emitted 1.1 times less CO than pine timber treated with the fire retardant solution B (standard research equipment).

3. The results of toxicity research obtained using nonstandard research equipment on flaming pine timber non-treated and treated with fire retardant solutions showed that:

- on average, the emission of $\mathrm{CO}$ from the nontreated pine timber starts at the beginning of the test while from pine timber treated with fire retardant solutions starts after $62 \mathrm{~s}$ from the beginning of the test;

- during the initial $180 \mathrm{~s}$ the emission of CO from pine timber treated with fire retardant solutions is 1.4 times lower than from non-treated pine timber;

- at the time interval of $180-460 \mathrm{~s}$ the emission of $\mathrm{CO}$ from pine timber treated with fire retardant solutions is 1.2 times higher than from the nontreated pine timber;

- the concentration of $\mathrm{CO}$ for flaming non-treated pine timber grows during the entire test while the concentration of $\mathrm{CO}$ for pine timber treated with fire retardant solutions alters insignificantly after $260 \mathrm{~s}$.

4. The results of toxicity determined by the standard research equipment on flaming pine timber non-treated and treated with fire retardant solutions prove that the emission of $\mathrm{CO}$ from pine timber treated with fire retardant solutions is 4.4 times higher than from non-treated pine timber.

5. Flaming pine timber treated with the fire retardant solution A emitted on average 1.15 times less CO than pine timber treated with the fire retardant solution B.

6 . While performing tests using the standard and non-standard research equipment, at the beginning of the tests the emission of $\mathrm{CO}$ from smouldering and flaming pine timber treated with fire retardant solutions is higher than from the non-treated pine timber. This is subjected to the reason that fire retardants reduce temperature on 
the surface of the specimens and the delivery of oxygen to the pyrolisis zone.

7. The correlation coefficient $r$ used for data analysis and defining the strength of dependence between curves and regression equations has shown that correlation link is strong enough. The lowest value of the correlation coefficient $r$ is 0.853 .

\section{References}

Babrauskas, V.; Blum, A.; Daley, R.; Birnbaum, L. 2011. Flame retardants in furniture foam: benefits and risks, Fire Safety Science 10: 265-278.

Bednarek, Z.; Griškevičius, M.; Šaučiuvėnas, G. 2009. Tensile, compressive and flexural strength reduction of timber in fire, Statybinès konstrukcijos ir technologijos [Engineering structures and technologies] 1(3): 148-156.

Bednarek, Z.; Kaliszuk-Wietecka, A. 2007. Analysis of the fireprotection impregnation influence on wood strength, Journal of Civil Engineering and Management 13(2): 7985.

Brushlinsky, N. N.; Hall, J. R.; Sokolov, S. V.; Wagner, P. 2012. World fire statistics. CTIF International Association of Fire and Rescue Services, 17. 64 p.

Capote, J. A.; Alvear, D.; Abreu, O.; Cuesta, A. 2012. Analysis of evacuation procedures in high speed trains fires, Fire Safety Journal 49: 35-46.

http://dx.doi.org/10.1016/j.firesaf.2011.12.008

Cheng, H.; Hadjisophocleous, G. V. 2011. Dynamic modeling of fire spread in building, Fire Safety Journal 46(4): 211224. http://dx.doi.org/10.1016/j.firesaf.2011.02.003

Drysdale, D. 1998. An Introduction to Fire Dynamics. 2nd Ed. England: John Wiley\&Sons. 447 p.

Fouladgar, M. M.; Yazdani-Chamzini, A.; Zavadskas, E. K.; Haji Moini, S. H. 2012. A new hybrid model for evaluating the working strategies: case study of construction company, Technological and Economic Development of Economy 18(1): 164-188.

http://dx.doi.org/10.3846/20294913.2012.667270

Frey, A.; Tissari, J.; Saarnio, K. M.; Timonen, H.; TolonenKivimäki, O.; Aurela, M.; Saarikoski, S. K.; Makkonen, U.; Hytönen, K.; Jokiniemi, J.; Salonen, R. O.; Hillamo, R. E. J. 2009. Chemical composition and mass size distribution of fine particulate matter emitted by a small masonry heater, Bolean Environment Research 14: 255-271.

Gaisru ir gelbejjimo darbu analize $2011 \mathrm{~m}$. [Fire and Rescue analysis]. 2011. Fire and Rescue Department under the Ministry of the Interior of the Republic of Lithuania, Vilnius, 2012. Available from Internet:

$<$ http://www.vpgt.lt/index.php?-13641674 98>.

Gałaj, J. 2009. A general concept of fire hybrid modelling in compartments, Journal of Civil Engineering and Management 15(3): 237-245.

http://dx.doi.org/10.3846/1392-3730.2009.15.237-245

Gałaj, J.; Karpovič, Z.; Jaskółowski, W. 2011a. Investigation into the influence of impregnation on pine timber combustion using a cone calorimeter and large scale tests, Statybines konstrukcijos ir technologijos [Engineering Structures and Technologies] 3(3): 91-104.

Gałaj, J.; Jaskółowski, W.; Karpovič, Z.; Šukys, R. 2011 b. Investigation of the influence of impregnation on the pine timber combustion using flow through tests, Bezpieczeństwo $i$ Technika Pożarnicza [Safety and Fire Technique] 3: 55-62.
Gann, R. G.; Babrauskas, V.; Grayson, S. J.; Marsh, N. D. 2011. Hazards of combustion products: toxicity, opacity, corrosivity, and heat release: The experts' views on capability and issues, Fire and Materials 35(2): 115-127. http://dx.doi.org/10.1002/fam.1043

Glenn, G. M.; Bingol, G.; Chiou, Bor-Sen.; Klamczynski, A. P.; Pan, Z. 2012. Sodium bentonite-based coatings containing starch for protecting structures in wildfire emergency situations, Fire Safety Journal 51: 85-92. http://dx.doi.org/10.1016/j.firesaf.2012.03.005

Grigonis, M.; Mačiulaitis, R.; Lipinskas, D. 2011. Fire resistance tests of various fire protective coatings, Medžiagotyra [Materials Science] 17(1): 93-98.

Hagen, M.; Hereid, J.; Delichatsios, M. A.; Zhang, J.; Bakirtzis, D. 2009. Flammability assessment of fire-retarded Nordic Spruce wood using thermogravimetric analyses and cone calorimetry, Fire Safety Journal 44(8): 1053-1066. http://dx.doi.org/10.1016/j.firesaf.2009.07.004

Hosoya, T.; Kawamoto, H.; Saka, S. 2007. Cellulosehemicellulose and cellulose-lignin interactions in wood pyrolysis at gasification temperature, Journal of Analytical and Applied Pyrolysis 80(1): 118-125. http://dx.doi.org/10.1016/j.jaap.2007.01.006

ISO 5660-1:2002. Reaction-to-fire tests - Heat release, smoke production and mass loss rate - Part 1: Heat release rate (Cone calorimeter method). International Organization for Standardization. $39 \mathrm{p}$.

Jeguirim, M.; Trouvé, G. 2009. Pyrolysis characteristics and kinetics of Arundo donax using thermogravimetric analysis, Bioresource Technology 100(17): 4026-4031. http://dx.doi.org/10.1016/j.biortech.2009.03.033

Jiang, J.; Li, J.; Hu, J. Fan, D. 2010. Effectofnitrogenphosphorusflameretardants on thermal degradation of wood, Construction and Building Materials 24(12): 2633-2637. http://dx.doi.org/10.1016/j.conbuildmat.2010.04.064

Juodeikiené, I. 2009. Influence of thermal treatment on the mechanical properties of pinewood, Medžiagotyra [Materials Science] 15(2): 148-152.

Karpovič, Z. 2009. Antipireniniais tirpalais impregnuotos medienos užsiliepsnojimo priklausomybè nuo medienos tankio [The flaming of timber treated with fire retardants depending on timber density], Mokslas - Lietuvos ateitis [Science - the Future of Lithuania] 1(5): 30-33.

Karpovič, Z.; Šukys, R. 2009. Pušies medienos ir kamštinio ažuolo pavojingumas smilkimo metu [Hazardousness of pine timber and cork oak during fumigation], Sveikatos mokslai [Health Sciences] 3: 2425-2429.

Karpovič, Z.; Jaskółowski, W.; Mačiulaitis, R.; Praniauskas, V. 2010. Antipireniniais ir antiseptiniais tirpalais impregnuotos medienos degimo tyrimai [Studies on combustibility of treated wood with fire retardant and antiseptic solutions], Annals of Warsaw University of life sciences SGGW. Forestry and wood technology [Varšuvos gyvenimo mokslu universiteto metraštis - SGGW. Miškininkyste ir medienos technologijos] 71: 342-346.

Kängsepp, K.; Larnoy, E.; Meier, P. 2011. The influence of sample origin on the leachability of wood preservatives, Medžiagotyra [Materials Science] 17(3): 282-286.

Keshavarz, G.; Khan, F.; Hawboldt, K. 2012. Modeling of pool fires in cold regions, Fire Safety Journal 48: 1-10. http://dx.doi.org/10.1016/j.firesaf.2011.11.003

Kleiza, J. 2003. Matematinis paketas MAPLE [Mathematical package MAPLE]. Vilnius: Technika. $87 \mathrm{p}$. 
Lestari, F.; Green, A. R.; Chattopadhyay, G.; Hayes, A. J. 2006. An alternative method for fire smoke toxicity assessment using human lung cells, Fire Safety Journal 41(8): 605615. http://dx.doi.org/10.1016/j.firesaf.2006.06.001

Mačiulaitis, R.; Praniauskas, V. 2010. Fire tests on wood products subjected to different heat fluxes, Journal of Civil Engineering and Management 16(4): 484-490. http://dx.doi.org/10.3846/jcem.2010.54

Nagrodzka, M.; Maloziec, D. 2011. Impregnation of the wood by flame retardants, Bezpieczeństwo $i$ Technika Pożarnicza [Safety and Fire Technique] 3: 69-75.

Papinigis, V.; Geda, E.; Lukošius, K. 2010. Design of people evacuation from rooms and buildings, Journal of Civil Engineering and Management 16(1): 131-139. http://dx.doi.org/10.3846/jcem.2010.12

Paul, K. T.; Hull, T. R.; Lebek, K.; Stec, A. A. 2008. Fire smoke toxicity: The effect of nitrogen oxides, Fire Safety Journal 43(4): 243-251. http://dx.doi.org/10.1016/j.firesaf.2007.10.003

Pereyra, A. M.; Giudice, C. A. 2009. Flame-retardant impregnants for woods based on alkaline silicates, Fire Safety Journal 44(4): 497-503. http://dx.doi.org/10.1016/j.firesaf.2008.10.004

Półka, M. 2008. The influence of flame retardant additives on fire properties of epoxy materials, Journal of Civil Engineering and Management 14(1): 45-48. http://dx.doi.org/10.3846/1392-3730.2008.14.45-48

Sakalauskas, V. 2003. Duomenu analize su statistica [Data analysis with statistics]. Vilnius: Margi raštai. 235 p.

Stec, A.; Hull, R. 2010. Fire toxicity. Woodhead Publishing Limited. 688 p. http://dx.doi.org/10.1533/9781845698072

Šaučiuvėnas, G.; Šapalas, A.; Griškevičius, M. 2011. Bearing capacity of axially loaded timber members - estimation under uneven fire action, Journal of Civil Engineering and Management 17(4): 581-589.

http://dx.doi.org/10.3846/13923730.2011.625655

Šukys, R.; Karpovič, Z. 2010. Research on toxicity of pine timber treated and non-treated with fire retardants, in The 10th International Conference "Modern Building Materials, Structures and Techniques": Selected papers, Vol. 2. Ed. by P. Vainiūnas, E. K. Zavadskas, 19-21 May, 2010, Vilnius, Lithuania, 1306-1313.

Teischinger, A. 2010. The development of wood technology and technology developments in the wood industries from history to future, European Journal of Wood and Wood Products 68(3): 281-287. http://dx.doi.org/10.1007/s00107-010-0458-2

Tserng, H. P.; You, J. Y.; Chang, C. Y.; Hsiung, K. H. 2011. The hot area evacuation model application in large scale gymnasiums, Journal of Civil Engineering and Management 17(2): 217-226.

Vaidogas, E. R.; Linkute, L.; Stulgys, D. 2012. Simulationbased predicting the position of road tank explosions. Part I: data and models, Transport 27(1): 14-24. http://dx.doi.org/10.3846/16484142.2012.663732

Vobolis, J.; Albrektas, D. 2009. Reduction of time consumption for wood impregnation, Medžiagotyra [Materials Science], 15(4): 321-324.

Wang, S.-Y.; Yang, T.-H.; Lin, L.-T.; Lin, C.-J.; Tsai, M.-J. 2008. Fire-retardant-treated low-formaldehyde-emission particleboard made from recycled wood-waste, Bioresource technology 99(6): 2072-2077. http://dx.doi.org/10.1016/j.biortech.2007.03.047

Windeisen, E.; Wegener, G. 2008. Behaviour of lignin during thermal treatments of wood, Industrial Crops and Products 27(2): 157-162.

http://dx.doi.org/10.1016/j.indcrop.2007.07.015

Zbignev KARPOVIČ. Master, doctoral student, Dept of Labour Safety and Fire Protection, Vilnius Gediminas Technical University (VGTU). Publications: 7 scientific publications. Research interests: fire retardants protective features, fire safety of impregnated timber.

Ritoldas ŠUKYS. Assoc. Prof. Dr, Head of Dept of Labour Safety and Fire Protection, Vilnius Gediminas Technical University (VGTU). Publications: author of more than 36 scientific publications. Research interests: human safety, safety engineering.

Rimvydas GUDELIS. Chief Specialist of Fire and Rescue Department under the Ministry of Interior. Research interests: fire fighting tactics, building materials and their analysis characteristics of fire. 